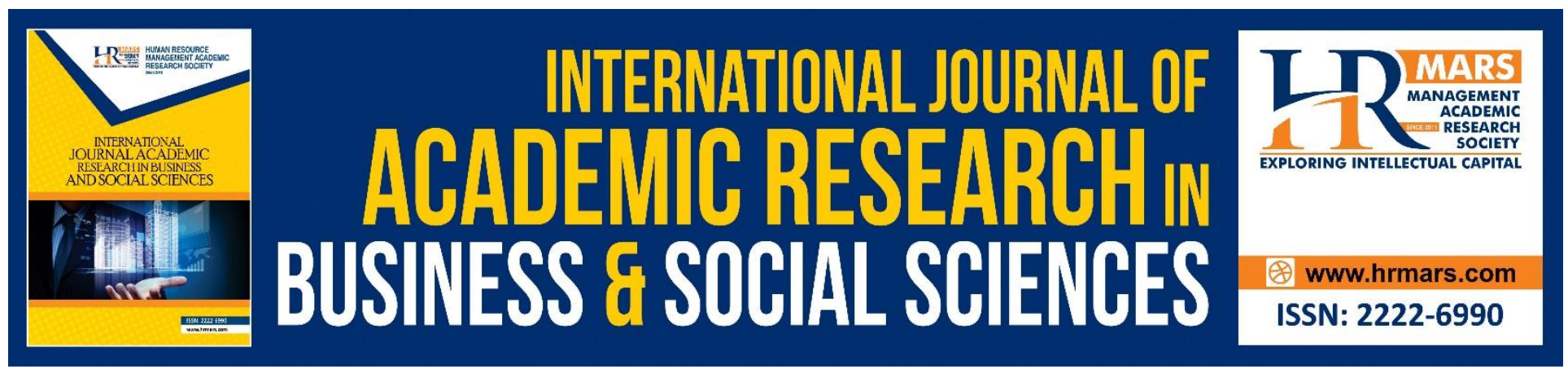

\title{
Analysis of the Acceptance of Newly Constructed Takaful Education Plan for Learning Disabled Children among Public
}

Puspa Liza Ghazali, Mustafa Mamat, Saiful Bahri Mohamed, Wan Muhamad Amir Wan Ahmad, Norfadzilah Rashid

To Link this Article: http://dx.doi.org/10.6007/IJARBSS/v8-i11/5200 DOI: $10.6007 /$ IJARBSS/v8-i11/5200

Received: 27 Oct 2018, Revised: 30 Nov 2018, Accepted: 03 Dec 2018

Published Online: 08 Dec 2018

In-Text Citation: (Ghazali, Mamat, Ahmad, \& Rashid, 2018)

To Cite this Article: Ghazali, P. L., Mamat, M., Ahmad, W. M. A. W., \& Rashid, N. (2018). Analysis of the Acceptance of Newly Constructed Takaful Education Plan for Learning Disabled Children among Public. International Journal of Academic Research in Business and Social Sciences, 8(11), 1413-1420.

\section{Copyright: (C) 2018 The Author(s)}

Published by Human Resource Management Academic Research Society (www.hrmars.com)

This article is published under the Creative Commons Attribution (CC BY 4.0) license. Anyone may reproduce, distribute, translate and create derivative works of this article (for both commercial and non-commercial purposes), subject to full attribution to the original publication and authors. The full terms of this license may be seen

at: $\underline{\text { http://creativecommons.org/licences/by/4.0/legalcode }}$

Vol. 8, No. 11, 2018, Pg. 1413 - 1420

Full Terms \& Conditions of access and use can be found at http://hrmars.com/index.php/pages/detail/publication-ethics 


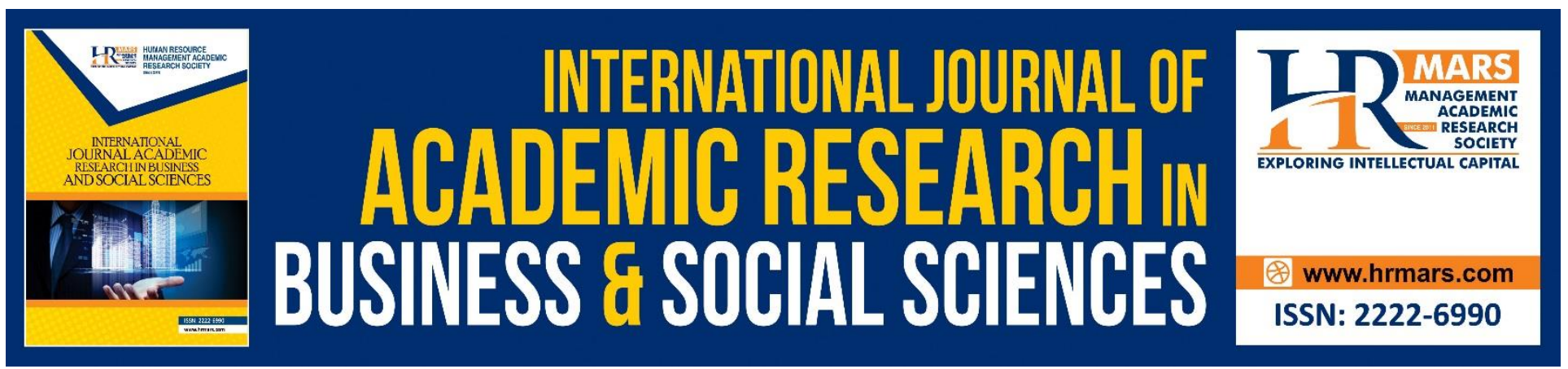

\title{
Analysis of the Acceptance of Newly Constructed Takaful Education Plan for Learning Disabled Children among Public
}

\author{
${ }^{1 *}$ Puspa Liza Ghazali, ${ }^{2}$ Mustafa Mamat, ${ }^{3}$ Saiful Bahri Mohamed, \\ ${ }^{4}$ Wan Muhamad Amir Wan Ahmad, ${ }^{5}$ Norfadzilah Rashid \\ 1,5Faculty of Economic and Management Sciences, Universiti Sultan Zainal Abidin. 21300 Kuala \\ Nerus. Terengganu. Malaysia. \\ $2 \&{ }^{3}$ Faculty of Informatics and Computing, Universiti Sultan Zainal Abidin. 22200 Besut. \\ Terengganu. Malaysia \\ ${ }^{4}$ School of Dental Sciences, Help Campus, Universiti Sains Malaysia. 16150 Kubang Kerian. \\ Kelantan. Malaysia. \\ Corresponding Author: nikmfadzilah@unisza.edu.my
}

\begin{abstract}
A new constructed takaful education plan for learning disabled children was constructed based on the Integration model. The aim of the study was conducted in order to investigate the acceptance of public on this newly constructed plan. A total of 400 respondents were chosen in the field study from 3 zones in Malaysia Peninsular; east zone (Terengganu and Kelantan), north zone (Kedah and Perlis) and middle zone (Selangor and Perak). The questionnaires distributed consist of six variables, where five were independent variables and one was dependent variable. By using a Spearman's correlation, it is found that each independent variable has strong correlation with the single variable. This can be concluded that the public has accepted this new constructed model. This study suggested that this new plan is implemented by takaful operators in Malaysia and also, for parents to choose takaful education plan that offer benefits that suit their child and affordable.
\end{abstract}

Keywords: Learning Disabled Children, Integration Model, Mudharabah, Wakalah and Takaful Education Plan.

INTRODUCTION

The purpose of takaful education plan is to provide a fund for higher education expenses for participants' children. Other than education fund as the policy matures, the plan also 
provides financial benefits if participants or parents suffer any set back covered under the plan (Insurance Info, 2007). Takaful education plan is grouped under family takaful plan, an alternative to life insurance, since Muslims are prohibited from involving themselves in any conventional insurance due to the three main prohibited elements which are usury, uncertainty and gambling (Dusuki and Abdullah, 2007).

The existence of takaful education plan shows the importance of providing a fund in order to a child can get a complete education. Financial constraint is one of the reasons of drop out or incomplete school year (Lehr et al., 2004). To get a complete education a right for all children, hence parents have to provide enough sources to fulfill it ("Right to Education", 2013). Even though parents have to spend almost half of their income for the education of their children, it is said that it is the best investment since it will affect a country development ("Education is Single Best Investment", 2015).

In Malaysia, children are lucky because they are given education facilities provided by the government. Even learning disabled children are included so they do not left behind. For learning disabled children, Malaysian government, under Ministry of Education, has provided almost 36 special schools for them included all types of disabilities ("Special education", 2015). In these schools, they are taught with basic learning such as reading, writing and arithmetic problem solving by trained teachers (Teoh et al., 2008).

The number of learning disabled children recorded by United Nations Children's Fund Malaysia (2014) shows the increasing pattern. In 2011, there are 134, 659 of learning disabled children recorded. In 2012, the number increases to 165, 281. Among the factors contribute to the increasing of number of learning disabled children are polluted environment (Fonken et al., 2011) and traumatic brain injury (Wu et al., 2004). The brain's defect due to these factors brought to the cognitive problem due to the crucial parts of brain is for processing the cognitive activities (Gaddes, 2013). It also interfere the digestion system and immune system of learning disabled children (Campbell-McBride, 2008). However, the defected brain can be reshaped with the help of suitable food supplement; fatty acid and vitamin D; and private tutor and this shows that learning disabled children are able to be alike their normal peer. However, not every child is fortunate to get all of these due to financial constraint faced by parents. The Malaysian cost of living shows the increasing pattern, shown by Consumer Price Index (CPI). The CPI for 2011 is 103. 2 and increase to 104.9 in 2012 (Department of Statistics Malaysia, 2013). Directly, the price of food supplement and class fee are increased.

From here, a new takaful education plan, known as takaful education plan with recovery model was constructed in order to give learning disabled children a special recovery fund for 3 years and also an education fund, as the policy mature. This plan is constructed to all participants' children. The recovery fund is only initiated if and only if the participants' children are diagnosed with learning disabilities. However, how far Malaysian will accept this newly constructed plan if it were released in market? 


\section{LITERATURE REVIEW}

The existing takaful education plans offered by takaful operators operated in Malaysia offer similar benefits and riders (Ghazali et al., 2011). Death coverage, total permanent disabilities (TPD) and academic performance award are the similar benefits offered. Riders offered are varies depending on the takaful operators and policy chosen. Five takaful education plans were compared their benefits and riders. The researchers found that the existing takaful education plan do not have special coverage for learning disabled children (Ismail et al., 2016). Parents have to manage the fund by their own in order to give their learning disabled child the food supplement and private tutor.

Integration model, found by Ghazali et al.(2012) were applied in this study. Under this model, all benefits and riders such as health, accident, hospital costs, loss of liability to work, critical illnesses, khairat, education, death benefit and death coverage can accumulated under one contribution life table. Under Integration model, the accumulated value, when it reaches its maturity, can have a big amount of money even though it has been initiated from small amount of contribution (Ghazali et al., 2015).

Based on the prospect theory developed by Kahneman and Tversky (1979), it stated that value is assigned to gains and losses rather than to final assets. People have an irrational tendency to be less willing to gamble with profits than with losses (Tvede, 1999). Hence, people might accept this newly constructed takaful education plan as learning disabilities also something that cannot be predicted yet every parent try their best to avoid the condition on their child or they will prepare every single basic needs for their child as their child was diagnosed with learning disabilities.

\section{METHODOLOGY}

\section{Investigating the acceptance of public on the newly constructed plan}

Based on survey by Ghazali et al., (2012), a field study was conducted to investigate the acceptance of public on the newly developed plan. 400 questionnaires were distributed into 3 zones; north zone (Kedah and Perlis), east zone (Kelantan and Terengganu) and middle zone (Selangor and Perak). Respondents were chosen among parent having at least 1 child and also have fixed monthly income. The questionnaire was adopted from Jun et al., (2014). The questionnaire has 2 main parts. First part is demographic profile such as age, number of dependent, level of education and so forth. Second part of the questionnaire is the questions with 5 Likert scale, where 1 is for strongly disagree and 5 for strongly agree.

There are 6 variables under second part due to there are 5 independent variables and 1 independent variable. The 5 independent variables are knowledge on takaful education plan, child and learning disabilities risk, social influence and perspective on new takaful education plan. The single independent variable is reason to participate on the newly constructed takaful education plan. A flowchart on how this 
new plan is working also provided in the questionnaire so that the respondent is able to get a glance on this new plan.

There were 5 hypotheses tested, denoted as $\mathrm{H}_{1}$ to $\mathrm{H}_{5}$, and is listed as in Table 1 below.

Table 1: List of Hypotheses

\begin{tabular}{|l|l|}
\hline & Hypothesis \\
\hline $\mathrm{H}_{1}$ & $\begin{array}{l}\text { Knowledge of takaful education plan among public has a } \\
\text { significant correlation on the acceptance of the new takaful } \\
\text { education plan for learning disabled children }\end{array}$ \\
\hline $\mathrm{H}_{2}$ & $\begin{array}{l}\text { Risk attitude among public has a significant correlation on the } \\
\text { acceptance of the new takaful education plan for learning } \\
\text { disabled children }\end{array}$ \\
\hline $\mathrm{H}_{3}$ & $\begin{array}{l}\text { Social influence in participating takaful education plan among } \\
\text { public has a significant correlation on the acceptance of the } \\
\text { new takaful education plan for learning disabled children }\end{array}$ \\
\hline $\mathrm{H}_{4}$ & $\begin{array}{l}\text { Child and learning disability risk has a significant correlation on } \\
\text { the acceptance of the new takaful education plan for learning } \\
\text { disabled children }\end{array}$ \\
\hline $\mathrm{H}_{5}$ & $\begin{array}{l}\text { Public view about new takaful education plan has a significant } \\
\text { correlation on the acceptance of the new takaful education } \\
\text { plan for learning disabled children }\end{array}$ \\
\hline
\end{tabular}

As the field study was completed, the responds then entered into Statistical Packages for Social Science (SPSS) version 21.Inferential statistics was adopted and correlation between 5 independent variables and single dependent variable was analyzed. The finding of the field study is presented in result part of this article.

\section{RESULTS AND DISCUSSIONS}

\section{Reliability Analysis}

Before the field study is started, a pilot test was done among 129 respondents. The purpose of conducting the pilot test is to test the reliability of the questionnaire. Below is the reliability analysis result of the pilot test. 
INTERNATIONAL JOURNAL OF ACADEMIC RESEARCH IN BUSINESS AND SOCIAL SCIENCES Vol. 8, No. 11, Nov, 2018, E-ISSN: 2222-6990 @ 2018 HRMARS

Table 2: Reliability Analysis

\begin{tabular}{|l|l|l|}
\hline Variables & Cronbach's Alpha & Number of Items \\
\hline $\begin{array}{l}\text { Acceptance of Public on New } \\
\text { Takaful Education Plan }\end{array}$ & 0.922 & 5 \\
\hline $\begin{array}{l}\text { View on Proposed Takaful } \\
\text { Education Plan }\end{array}$ & 0.836 & 3 \\
\hline $\begin{array}{l}\text { Child and Learning Disability } \\
\text { Risk }\end{array}$ & 0.757 & 5 \\
\hline Social Influence & 0.956 & 5 \\
\hline Risk Averter Takaful & 0.778 & 3 \\
\hline $\begin{array}{l}\text { Knowledge on } \\
\text { Education Plan }\end{array}$ & 4.924 & 4 \\
\hline
\end{tabular}

\section{Normality Test}

Since researchers want to apply inferential statistics in this study, normality test was conducted as its prerequisite (Ghasemi and Zahediasi, 2012). By using Kolmogorov-Smoivor statistics, with a Lilliefors significance level and Shapiro-Wilk statistics (Pallant, 2007), it shows that the collected data were not normally distributed.

\section{Correlation Result}

Spearman's correlation analysis is able to measure the strength and the relationship between two variables. Table 4 below shows the correlation result at $1 \%$ significance level.

Table 4: Correlation Result

\begin{tabular}{|l|l|l|}
\hline Variable & $\begin{array}{l}\text { Spearman's } \\
\text { Correlation, } \mathbf{r}_{\mathbf{s}}\end{array}$ & $\mathbf{p}$ \\
\hline $\begin{array}{l}\text { Acceptance of Public on New Takaful } \\
\text { Education Plan }\end{array}$ & 1 & \\
\hline Knowledge on Takaful Education Plan & 0.534 & 0.00 \\
\hline Risk Attitude & 0.520 & 0.00 \\
\hline Social Influence & 0.520 & 0.00 \\
\hline Child and Learning Disability Risk & 0.491 & 0.00 \\
\hline View on Proposed Takaful Education Plan & 0.707 & 0.00 \\
\hline
\end{tabular}

Since all correlation among 5 independent variables and single dependent variable are above 0.4 , it can be said that all the 5 hypotheses were accepted. Hence, this shows that public is accepting this newly constructed plan and they may tend to participate into this plan if this plan is available in market.

For the first hypothesis, $\mathrm{H}_{1}$, stated that knowledge of takaful education plan among public has a significant correlation on the acceptance of the new takaful education plan for learning 
disabled children; second hypothesis, $\mathrm{H}_{2}$, risk averter among public has a significant correlation on the acceptance of the new takaful education plan for learning disabled children; third hypothesis, $\mathrm{H}_{3}$, social influence in participating takaful education plan among public has a significant correlation on the acceptance of the new takaful education plan for learning disabled children; fourth hypothesis, $\mathrm{H}_{4}$, child and learning disability risk has a significant correlation on the acceptance of the new takaful education plan for learning disabled children; and fifth hypothesis, $\mathrm{H}_{5}$, public view about new takaful education plan has a significant correlation on the acceptance of the new takaful education plan for learning disabled children.

\section{CONCLUSION}

From the correlation result, it can be concluded that public has accepted this newly constructed takaful education plan for learning disabled children. Apart from the complete benefits offered, this new plan was constructed for all income level. The acceptance of public also shows the awareness of having a protection for the children and also the preparation of education fund from early age of child. With the rising cost of living shown by CPI, this also affecting education cost. Hence, this new plan is able to help every parent in providing enough funds for tertiary education and on the same time, they get protection for themselves and their beloved child.

\section{REFERENCES}

Campbell-McBride, N. (2008). Gut and psychology syndrome. Journal of Orthomolecular Medicine, 23(2), 90-94.

Department of Statistics Malaysia. (2013). Consumer price index. Retrieved from https://www.statistics.gov.my/index.php?r=column/ctimeseries\&menu id=NHJlaGc2Rlg4Z XIGTjh1SU1kaWY5UT09

Dusuki, A. W. and Abdullah, N. (2007). Why do Malaysian customers patronice Islamic bank? International Journal of Bank Marketing. 25(3), 142-160

Education is a single best investment in prosperous, healthy and equitable societies. (2015). Retrieved from http://www.canadianfeedthechildren.ca/what/education

Fonken, L. K., Xu, X., Weil, Z. M., Chen, G., Sun, Q., Rajagopalan, S., \& Nelson, R. J. (2011). Air pollution impairs cognition, provokes depressive-like behaviors and alters hippocampal cytokine expression and morphology. Molecular Psychiatry,16(10), 987-995.

Gaddes, W. H. (2013). Learning disabilities and brain function: A neuropsychological approach. Springer Science \& Business Media.

Ghasemi, A., \& Zahediasl, S. (2012). Normality tests for statistical analysis: a guide for nonstatisticians. International Journal of Endocrinology and Metabolism, 10(2), 486-489. 
INTERNATIONAL JOURNAL OF ACADEMIC RESEARCH IN BUSINESS AND SOCIAL SCIENCES Vol. 8, No. 11, Nov, 2018, E-ISSN: 2222-6990 @ 2018 HRMARS

Ghazali, P. L., Abu Bakar, N. M., Mohd Tahir, I., Haron, M., Wan Ismail, W. Z. and Mamat, M., (2015). Optimization of Integration Model in family Takaful. Journal of Applied Mathematics Sciences, 9(39), 1899-1909.

Ghazali, P. L., Mohd, I., Mamat, M. and Wan Ahmad, W. M. A., (2012a). Integration Model of Education Plan Takaful: A Case Study for Terengganu, Kelantan and Perlis, States in Malaysia. Far East Journal of Mathematical Sciences (FJMS), 65(1), 97-117.

Ghazali, P. L., Ismail, M., Mamat, M. and Wan Ahmad, W. M. A., (2012b). Integration Model in Premium Life Table of Family Takaful. Journal of Applied Sciences Research, 8(7), 3763-3776.

Ghazali, P. L., Ismail, M., Mamat, M. and Wan Ahmad, W. M. A., (2011). Mathematical Modelling in Family Takaful. Journal of Applied Sciences, 11(2), 3381-3388.

Insurance Info (2007). Retrieved from http://www.insuranceinfo.com.my/choose your takaful/protect your family/child educ ation plan.php?intPrefLangID=1.

Ismail, S. A., Ghazali, P. L., Baharazi, N. Z., Amran, N. A., Salleh, F. Omar, L., Syed Jaafar, S. A. S. and Mamat, M. (2016). Application of Integration Model for Recovery Fund in Takaful Education Plan. Far East Journal of Mathematical Sciences), 100(2), 301-313.

Jun, B. N. W., Harn, F. L., Theng, G. L., Yee, T. X. and Choon, T. Y. (2014). The determinants on health and life insurance demand among Malaysian. (Doctoral dissertation, Universiti Tunku Abdul Rahman), Kuala Lumpur.

Kahneman, D., \& Tversky, A. (1979). Prospect theory: An analysis of decision under risk. Econometrica: Journal of The Econometric Society, 12(3), 263-291.

Lehr, C. A., Johnson, D. R., Bremer, C. D., Cosio, A., \& Thompson, M. (2004). Increasing Rates of School Completion: Moving from Policy and Research to Practice. A Manual for Policymakers, Administrators, and Educators. Essential Tools. National Center on Secondary Education and Transition, University of Minnesota (NCSET), St. Paul, MN, USA.

Pallant, J. (2007). SPSS survival manual: A step-by-step guide to data analysis using SPSS version 15. Nova lorque: McGraw Hill.

Right To Education Project. (2013). Understanding education as a right. Retrieved from http://www.right-to-education.org/page/understanding-education-right

Sekaran, U. and Bougie, R. (2006). Research methods for business: A skill building approach. John Wiley \& Sons.

Special education- Special needs public schools of Ministry of Education. (2015). Retrieved from http://www.schoolmalaysia.com/school/list.php?type $=11 \mathrm{C}$

Teoh H.J., Cheong S. K. \& Woo P.J. (2008). Student learning disability experiences, training and services needs of secondary school teachers. The Malaysian Journal of Psychiatry, 17(2), 112-119.

Tvede, L. (1990). The psychology of finance. A Scandinavian University Press Publication. 